PERM JOURNAL OF PETROLEUM AND MINING ENGINEERING

ВЕСТНИК ПНИПУ. ГЕОЛОГИЯ. НЕФТЕГАЗОВОЕ И ГОРНОЕ ДЕЈО

ISSN 2224-9923

Volume/ Том 17 №1 2018

http://vestnik,pstu.ru/geo/

УДК 622.8:614.82

Article / Статья

(C) PNRPU / ПНИПУ, 2018

\title{
JOINT EFFECT OF PHYSICAL FACTORS OF DIFFERENT NATURE ON THE HUMAN
}

Aleksandr I. Sidorov, Ekaterina V. Zykina, Aleksey V. Kudryashov, Alisa S. Kalinina

South Ural State University (National Research University) (76 Lenina st., Chelyabinsk, 454080, Russian Federation)

\section{СОЧЕТАННОЕ ДЕЙСТВИЕ НА ЧЕЛОВЕКА ФИЗИЧЕСКИХ ФАКТОРОВ РАЗЛИЧНОЙ ПРИРОДЫ}

\section{А.И. Сидоров, Е.В. Зыкина, А.В. Кудряшов, А.С. Калинина}

Южно-Уральский государственный университет (национальный исследовательский университет)

(454080, Россия, г. Челябинск, пр. Ленина, 76)

Получена / Received: 02.09.2017. Принята / Accepted: 12.02.2018. Опубликована / Published: 30.03 .2018

\section{Key words:}

high frequency electric current, electrical safety criteria, working conditions, noise, vibration, dustiness, microclimate, joint effect, mining industry.

\begin{abstract}
Modern working conditions of miners in the mining industry are characterized by intensive noise and vibration, high dustiness, unfavorable microclimate, the levels of which often exceed hygienic standards. Unfortunately, the current regulatory framework does not take into account the fact that in real life most of the production personnel are exposed not to one but several factors of the working environment at the same time. Thus, the sanitary standarts established for factors that act singularly and guarant the preservation of health precisely for these conditions may be untenable. Ensuring sustainable safety when working in electrical installations should be achieved by complying with electrical safety requirements. But permissible levels of contact currents and voltages currently recommended by the International Electrotechnical Commission do not take into account the joint effect of electric current and other physical factors, and noise in particular. The effect of sound pressure level and its frequency on the resistance of the human body is proved earlier in V.V. Katsay's thesis. The study of the effect of noise on magnitude of threshold perceptible current is resumed in laboratory conditions at the Department of Life Safety of the South Ural State University. To obtain reliable results a test complex was designed and built. The complex includes a muffled chamber, sources of simulated voltages and noise, a block of recording instruments. Primary electrical safety criteria are investigated for an increased frequency $(5000 \mathrm{~Hz})$ under the influence of noise load. Voltages and currents that cause feelings are measured before the impact of noise and under the influence of noise with a sound pressure level of $97 \mathrm{~dB}$.

The dependence built calls into question the result obtained from results of previous studies on the need to reduce settings at which tools of safety shutdown trigger.
\end{abstract}

Современные условия труда горнорабочих в горнодобывающей промышленности характеризуются интенсивным шумом и вибрацией, высокой запыленностью, неблагоприятным микроклиматом, уровни которых часто превышают гигиенические нормативы. К сожалению, действующая нормативная база не учитывает того, что в реальной жизни большая часть производственного персонала подвергается воздействию не одного, а нескольких факторов рабочей среды одновременно. Таким образом, санитарные нормы, установленные для изолированно действующих факторов и гарантирующие сохранение здоровья именно для этих условий, могут оказаться несостоятельными. Обеспечение устойчивой безопасности при работах в электроустановках должно достигаться путем соблюдения требований электробезопасности. Но рекомендуемые в настоящее время Международной электротехнической комиссией предельно допустимые уровни токов и напряжений прикосновения не учитывают совместного действия электрического тока и иных физических факторов, в частности шума. Ранее в диссертационной работе В.В. Кацай было доказано влияние уровня звукового давления и его частоты на сопротивление тела человека. На кафедре безопасности жизнедеятельности Южно-Уральского государственного университета были возобновлены в лабораторных условиях исследования влияния шума на величину порогового ощутимого тока. Для получения достоверных результатов был спроектирован и создан испытательный комплекс, включающий в себя заглушенную камеру, источники моделируемых напряжений и шума, блок регистрирующих приборов. Были проведены исследования первичных критериев электробезопасности для повышенной частоты (5000 Гц) при воздействии шумовой нагрузки. Измерялись напряжения и токи, вызывающие ощущения, до воздействия шума, а также при воздействии шума с уровнем звукового давления 97 дБ.

Построенная зависимость ставит под сомнение полученный по итогам прошлых исследований результат о необходимости снижения уставок срабатывания устройств защитного отключения.

Aleksandr I. Sidorov (Author ID in Scopus: 57169723300) - Doctor of Engineering, Professor, Head of the Department of Life Safety (tel.: +007 35126794 49, e-mail: bgd-susu@mail.ru).

Ekaterina V. Zykina - Senior Lecturer at the Department of Life Safety (tel.: +007 35126797 54, e-mail: zykina_ev@mail.ru). The contact person for correspondence Aleksey V. Kudryashov (Author ID in Scopus: 57194217164) - PhD in Engineering, Associate Professor at the Department of Life Safety (tel.: +007 351 267 95 56, e-mail: arm174@arambler.ru). Alisa S. Kalinina (Author ID in Scopus: 57194219001) - Associate Professor at the Department of Life Safety (tel.: +007 351 267 95 56, e-mail: alisa.charm@mail.ru).

Сидоров Александр Иванович - доктор технических наук, профессор, заведующий кафедрой безопасности жизнедеятельности (тел.: +007 3512679449 , е-таil: bgd@susu.ru).

Зыкина Екатерина Викторовна - старший преподаватель кафедры безопасности жизнедеятельности (тел.: +007 3512679754 , e-mail: zуkina_ev@mail.ru). Контактное лицо для переписки

Кудряшов Алексей Валерьевич - кандидат технических наук, доцент кафедры безопасности жизнедеятельности (тел.: +007 351267 95 56, e-mail: arm174@rambler.ru). Калинина Алиса Сергеевна - доцент кафедры безопасности жизнедеятельности (тел.: +007 35126795 56, e-mail: alisa.charm@mail.ru). 


\section{Introduction}

Work activities of miners are characterized by a complex of production and environment factors. Physical factors such as noise, vibration, unfavorable microclimate and high dustiness are the main component of such a complex.

Under certain conditions, a sequential or simultaneous (joint) effect on the human body of each of them can cause more significant consequences than with a single action.

Usually, there are potentiation, antagonism or independent effect observed when combined physical and chemical factors of high effect levels. Additive dependences may appear in the opposite case. Response of the body for combined effects of industrial factors is determined by their physical levels, functional state of master systems of the worker's body and its individual sensitivity to an irritant.

Assessing the combined effect of unfavorable factors of the working environment, it should be kept in mind that in case of low intensities changes in the body can represent disruptions of adaptation mechanisms. In case of long-lasting effect of levels that are considerably higher than hygienic standards frequency of occupation-caused diseases increases, nature of their history may change or new forms of illness may appear

\section{Features of mining industry working conditions}

Modern working conditions of workers in the mining industry as was already mentioned are characterized by intense noise and vibration, high dustiness, unfavorable microclimate, levels of which often exceed hygienic standards [1].

Results of assessments of working conditions show that the dust effect on the organism of miners exceeds the influence of other factors of the corresponding industrial environment [2]. Dust forms during the destruction and crushing of the rock massif, loading and transportation of the rock. Average dust concentrations during the drilling are $22.3-38.6 \mathrm{mg} / \mathrm{m}^{3}$, for loaing and transportation jobs - 13.2-28.6 $\mathrm{mg} / \mathrm{m}^{3}$, which exceeds the hygienic standards in 2.4 times and more $[3,4]$. The highest dust concentrations (tens and hundreds of $\mathrm{mg} / \mathrm{m}^{3}$ ) are observed when working in mines of the Far North in the frozen and thawed rocks zone. They are caused by ineffective use or absence of dust suppression means. In mines where automated mining equipment with diesel drive is used the air of working areas is significantly polluted by both dust and components of exhaust gases and various organic compounds. Gaseous exhaust products are sorbed on dust and soot particles, increasing the fibrogenicity of dust and complicating its chemical composition.

Miners work in unfavorable microclimate conditions [3-5]. Working conditions such as low freezing temperatures of air and rocks of Far North permafrost affect miners all year round. Microclimate of mines depends on the region climatic conditions, temperature of rocks being developed and distance between the excavations and air supply shaft. Microclimate parameters in the mines vary within very wide limits (air temperature from -30 to $+31^{\circ} \mathrm{C}$, relative humidity $30-100 \%$, air speed 0.1 to $6 \mathrm{~m} / \mathrm{s}$ ).

All types of mining equipment used in underground and open pits are sources of noise. They include main and partial fans, pumping drainage systems, transformer substations and rectifiers, compressor and refrigeration equipment with a continuous operation cycle. Inconstant noise in the mine appears during the cleaning and roadheaders, movement of vehicles, operation of manual mechanized tools, lifting 
machines. Sound waves arise during blasting operations. According to [4], high noise levels are recorded at the workstations of machinists, miners and workers of other professions: drilling rigs - 95-105 dBA, roadheaders 95-100 dBA, coal-mining combines - 85-95 dBA, electric locomotives - 80-95 dBAv. A high level of noise (more than $100 \mathrm{dBA}$ at workplaces of machinists of the rock loader and ventilation units) is mentioned in [3].

Pneumatic jackhammers, perforators, hydraulic monitors serve as sources of local vibration. Sound levels of coal combines, mine transport are associated with effects of general vibrations of low and medium frequencies and exceed the standard ones (by $8 \mathrm{~dB}$ or more) [6].

There is no daylight in mines. All works and movements in mines occur under artificial lighting.

The most dangerous production factors of underground mining of coal seams are methane release from the massif, formation of an explosive mixture when methane is mixed with mine air, spontaneous coal combustion [7].

Working conditions in quarries of various regions differ significantly from underground works of coal and ore extraction. They have their own features depending on geographic, climatic, mining and geological conditions (south, the Far North etc.). The effect of unfavorable factors during such jobs is much lower. At the same time, the operation of all machines is accompanied by the generation of noise and vibration, levels of which often exceed permissible ones. Their characteristics depend on the type of machines, work cycle, degree of deterioration of equipment, strength of rocks etc. [4].

Differences in production technologies have a significant impact on the formation of working conditions that continue to be harmful, are characterized by frequent excesses of hygienic standards and determine the high professional risk of disrupting the miners' health. Preventive actions against the adverse effects on humans are aimed to reduce the impact of hazardous and harmful production factors to a safe level based on their hygienic rationing. Most of the standards established for the maximum permissible concentration, maximum permissible level (MPC, MPL) represent the experimentally established maximum permissible values. Unfortunately, the current regulatory framework does not take into account the fact that in real life most of the production personnel are exposed not to one but several factors of the working environment at the same time. Since the sanitary standards established for single factors and ensuring safety for these conditions in case of several factors joint can be untenable, that is extremely important to study the nature of the effects of joint action for occupational health. For example, it is noted in [8-10] that the joint effect of harmful production factors adversely affects the functional state of the organism as a whole and in a number of cases promotes the development of occupational diseases, even with small and medium intensity of their parameters.

The joint action of physical factors with harmful matter is mentioned in scientific references more often. It is known that the toxicity of poisons in the body in a certain temperature range is the smallest, intensifying both with increasing and decreasing air temperature. High air humidity and changes in barometric pressure increase the risk of poisoning. Noise and vibration always increase the toxic effect of industrial poisons. Under the ultraviolet radiation sensibilization of the body to the action of certain harmful substances is 
possible. Most often there are various dust and gas compositions both in production and terrestrial environment as a whole. In addition, ultraviolet radiation has an effect on the interaction of gases in atmospheric air and promotes the smog formation.

The joint effect of noise and heating microclimate is mentioned in the papers of domestic and foreign scientists. In that case there are more significant changes in the functional state of person and decrease in his capacity for work than with an isolated effect of the factors mentioned $[11,12]$. The authors note the important fact of negative joint influence of heat and sound on the efficiency and intensity of labor of workers, the need to establish safe noise levels and microclimate parameters taking into account their joint effect. It is said in [13] that the joint action of a heating microclimate and noise at a level higher than the MPL is accompanied by a large increase in the incidence with a temporary loss of ability to work according to the class of diseases of the circulatory system (hypertension). The results of studies of joint effects of noise, vibration, low temperature and heating microclimate $[11,14-16]$ indicate the methodological complexity of evaluating the joint effect of factors, since the biological effect is not an algebraic sum of independent impacts.

It is also known that noise, especially intermittent, affects the electrical characteristics of the human body [17], in particular, its resistance to electric current. The effect of noise on human electrophysiology was noted in [18]. However, the nature of this phenomenon was not detected. In addition to the effect on organs of hearing, noise causes changes in the functional state of the body and affects the mental state of a person. These circumstances significantly increase the risk of workers' electrical damage.

\section{Studies of the joint action \\ of high frequency $(5000 \mathrm{~Hz})$ electric current and noise}

Permissible levels of currents and contact voltages currently recommended by the International Electrotechnical Commission do not take into account the joint effect of electrical current and other physical factors and noise in particular.

For this purpose, the Department of Life Safety of the South Ural State University continues to study the effect of noise on the threshold sensible current in the laboratory conditions. In order to obtain reliable results a test complex was designed and built including the blanked off chamber, sources of modeled voltages and noise and block of recording instruments [19-21]. Modelled voltages have such the features as possibilities of obtaining the influencing signals of any shape and frequency as well as ensuring the constant rate of increase of the signals.

Locomotive transport is the main transport in horizontal shafts of the mines. Among the known types of mine locomotives non-contact electric locomotives in the complex of electrical equipment of which the principle of electromagnetic transmission of energy of increased frequency to mobile objects have significant advantages [22].

Primary electrical safety criteria were studied having electric high frequency current $(5000 \mathrm{~Hz})$ and noise joint. Studies were performed considering the probability of body damage by electric current during the operation of electric locomotives of alternating current of high frequency with inductive energy transfer was considered.

The studies were carried out in the "handhand" way. Voltages and currents causing feelings 
with no noise impact and with noise impact were measured. The voltage applied to the electrodes gradually increased from 0 to $20 \mathrm{~V}$. Thanks to use of a PC, the rate of increase of that signals was constant in all experiments. In addition, at the same low voltage of $2.6 \mathrm{~V}$, electrical resistance of the body of each subject was determined. According to [23], the resistance of the human body depends on the applied voltage, starting from $3 \mathrm{~V}$. In order to exclude the influence of this parameter on the measurement results, the value was used.

Noise load was evaluated on the basis of a dose approach. From the physical point of view, the equivalent sound level and noise dose are analogous and connected mathematically [2428]. In order to reduce the time, duration of the noise load impact during one experiment was assumed equal to 30 minutes. The experimental installation developed allows to simulate the acoustic load with any parameters at the choice of researcher and provide the necessary relative dose of noise $\left(D_{\text {rel }}\right)$ for the selected time interval. According to the technique [29], simulated load must correspond to the noise load per shift, i.e. $\mathrm{D}_{\text {rel }}=100 \%$. It is also assumed that working conditions meet allowable for the noise factor values $(80 \mathrm{dBA})$. Considering the duration of each experiment equal to 30 minutes, the equivalent sound level was obtained as a function of the relative noise dose in accordance with GOST 12.1.003-83:

$$
L_{\text {equiv }}=4,3536 \ln \left(D_{\text {rel }}\right)+76,972 .
$$

The dependence given above (with the reliable value of approximation equal to 1) allowed performing the reverse calculation of equivalent sound level applied to experimental conditions. Obtained sound level values and the measured values of threshold perceptible current are given in the table.

The function of the threshold perceptible current of equivalent sound level at high-frequency voltage is shown in Fig. $a$.

Experimental data $\left(f_{\text {cur }}=5000 \mathrm{~Hz}\right)$

\begin{tabular}{|c|c|}
\hline $\begin{array}{c}\text { Equivalent sound } \\
\text { level, dBA }\end{array}$ & $\begin{array}{c}\text { Magnitude of threshold } \\
\text { perceptible current, mA }\end{array}$ \\
\hline 77 & 8.02 \\
\hline 89 & 8.29 \\
\hline 92 & 8.62 \\
\hline 94 & 8.6 \\
\hline 95 & 8.77 \\
\hline 96 & 8.83 \\
\hline 97 & 8.86 \\
\hline
\end{tabular}

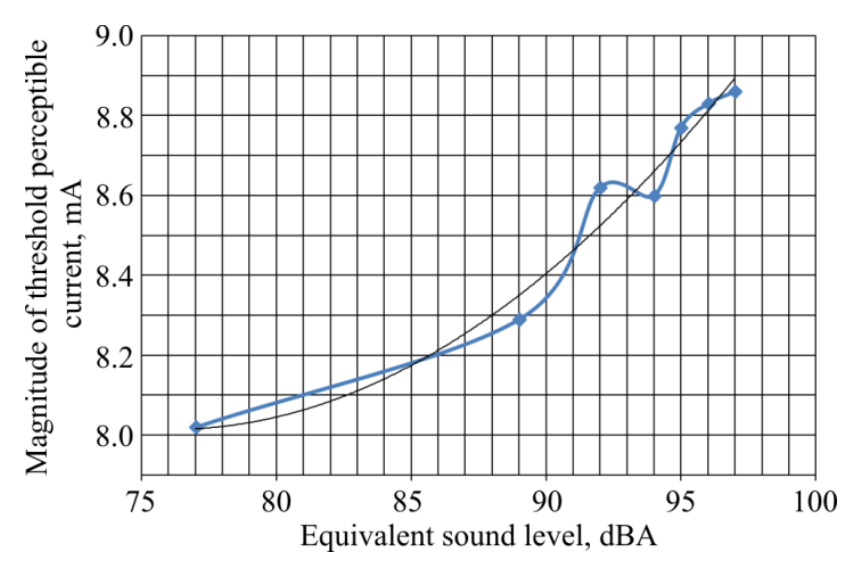

$a$

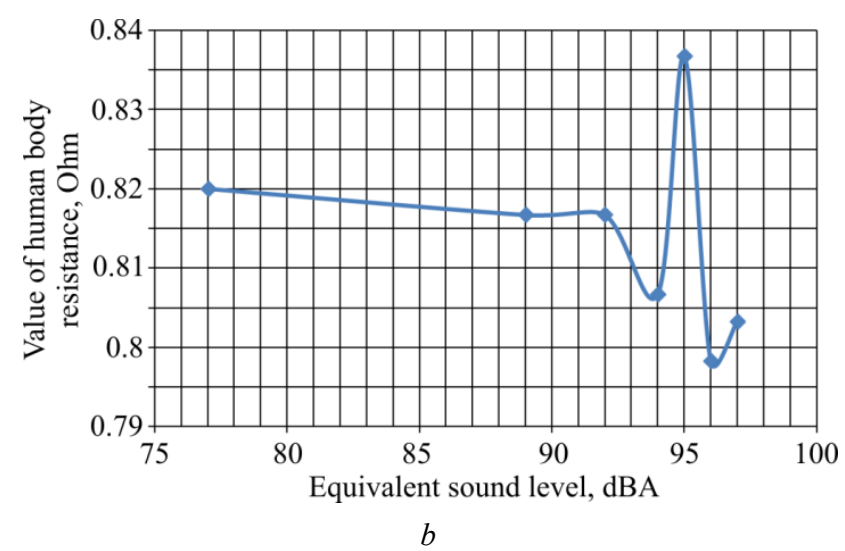

Fig. Function of the threshold value of sensible current $(a)$ and resistance of the human body to electric current $(b)$ on the equivalent sound level $\left(f_{\text {cur }}=5000 \mathrm{~Hz}\right)$ 
From the mathematical point of view, the function acquires a $2^{\text {nd }}$ order polynomial character:

$$
I_{\text {poten }}=0,002 L_{\text {equiv }}^{2}-0,3052 L_{\text {equiv }}+19,617 \text {. }
$$

The approximation reliability value in our case was 0.9666 .

It should be noted that the measured values of threshold perceptible currents (more than $8 \mathrm{~mA}$ ) exceed the primary electrical safety criteria for currents of $5000 \mathrm{~Hz}(5.2 \mathrm{~mA})$, proposed in [30].

At the same time, studies of changes in the electrical resistance of the human body were carried out (Fig. $b$ ).

According to results of the research, the fluctuations in resistance of a human body to an electric current when exposed to noise during a working shift do not have a clearly expressed functional dependence. In this case, the oscillation interval is of the order of $0.03 \mathrm{k} \Omega$.

\section{Conclusions}

In order to overcome the challenges connected to the safety of electrical equipment operation electrical safety criteria have to be considered. Analysis of scientific electrotechnical references revealed that there is no information for the effect on primary safety criteria, including for high-frequency current, harmful production factor "noise". According to the information on working conditions of personnel operating and servicing electrical installations and to the factor under consideration, it is necessary to carry out appropriate studies.

From the theoretical point of view the studies will allow expanding understanding the factors that affect the result of electrical injury in working conditions. Practical outcome can be implemented in use of the results obtained while developing the calculation methodology for the formation of the safe properties of a complex of electrical equipment for rail transport with inductive energy transmission.

\section{References}

1. Skripal' B.A. Professional'naia zabolevaemost', ee osobennosti na predpriiatiiakh gorno-khimicheskogo kompleksa Kol'skogo Zapoliar'ia [Occupational illness, its features at the enterprises of the mining and chemical complex of the Kolskoye Peninsula]. Ekologiia cheloveka, 2008, no.10, pp.26-30.

2. Oks E.I., Kurakin V.A., Abashkin A.O. Otsenka uslovii truda $\mathrm{i}$ raschet dopustimogo (bezopasnogo) stazha osnovnykh professii ugol'nykh shakht Kuzbassa [Assessment of working conditions and calculation of permissible (safe) work experience of major worker groups in Kuzbass mining]. Meditsina truda $i$ ekologiia cheloveka, 2015, no.3, pp.147-150.

3. Zakharenkov V.V., Kislitsyna V.V. Gigienicheskaia otsenka uslovii truda i 2017). professional'nogo riska dlia zdorov'ia rabotnikov ugol'noi shakhty [Hygienic evaluation of the working conditions and occupational risk for health of the workers of a coal mine]. Uspekhi sovremennogo estestvoznaniia, 2013, no.11, pp.14-18.

4. Chebotarev A.G. Sovremennye usloviia truda na gornodobyvaiushchikh predpriiatiiakh i puti ikh normalizatsii [Current working environment at mines and ways of its improvement]. Gornaia promychlennost', 2012, no 2, available at: http://mining-media.ru/ ru/article/prombez/2499-sovremennye-usloviyatruda-na-gornodobyvayushchikh-predpriyatiyakhi-puti-ikh-normalizatsii (accessed 15 August 
5. Teregulova Z.S., Tairova E.I., Karimova L.K., Iskhakova D.R., Abdrakhmanova E.R. Osobennosti formirovaniia professional'noi zabolevaemosti u rabochikh gornorudnykh predpriiatii [Occupational morbidity development in mining industry workers]. Biulleten' VSNTs SO RAMN, 2006, no.3, pp.109-110.

6. Vliianie vzryvoopasnykh gazov, shuma i vibratsii ugol'nykh shakht na organizm. Nistagm uglekopov [Influence of explosive gases, noise and vibration of coal mines on the body. Nystagmus of coal miners]. Gigiena truda. Sait, available at: http://meduniver.com/Medical/gigiena_truda/213.h tml (accessed 15 August 2017).

7. Kolesnichenko E.A., Kolesnichenko I.E. Prichiny i vozmozhnye metody predotvrashcheniia vzryvov metana i pozharov $\mathrm{v}$ shakhtakh Rossii [Causes and possible methods of preventing methane and fire explosions in the mines of Russia]. Gornaia promyshlennost', 2004, no.1, available at: http://mining-media.ru/ru/article/ prombez/1419-prichiny-i-vozmozhnye-metodypredotvrashcheniya-vzryvov-metana-i-pozharov-vshakhtakh-rossii (accessed 17 August 2017).

8. Afanasieva R.F. Preventive measures of workers in cooling condition: hygienic and clinical bases of assessment and development. Problems with cold work. Int. Symposium. Stockholm, 1997, pp.19-25.

9. McCarty D. Arthritis allied conditions. A Textbook of rheumatology, 1988, pp.224-241.

10. Petrichenko S.I. Vliianie uslovii truda i byta lits geologicheskikh professii na zabolevaemost' arterial'noi gipertoniei i ishemicheskoi bolezn'iu serdtsa [Influence of working and living conditions of persons of geological professions on the incidence of arterial hypertension and coronary heart disease]. Abstract of Ph. D. thesis. Moscow, 1997, 24 p.
11. Rentzsch M., Presher W., Weinrich W. Combined effect of selected parameters of climate and noise on labour efficiency and stain. Combined effects of environmental factors. Ed. by O. Manninen. Tampere, 1984, pp. 99-115.

12. Sakakibara H., Kondo T., Koike Y. et al. Combined effects of vibration and noise palmar sweating in healthy subjects. European Journal of Applied Physiology and Occupational Physiology, 1989, vol.59, iss.3, pp.195-198. DOI: 10.1007/BF02386187.

13. Babaian M.A., Denisov E.I. Sochetannoe deistvie shuma, tepla i otsenka ikh biologicheskoi ekvivalentnosti [Joint effect of noise, heat and estimation of their biological equivalence]. Gigiena truda $i$ profzabolevaniia, 1991, no.9, pp.24-26.

14. Burstrom L. The influence of noise and temperature on the absorption of vibration energy in the hand. Archives of Complex Environmental Studies, 1995, 7(34), pp.91-95.

15. Manninen O. Increased loss of hearing due to combined noise and low frequency vibration. 28th Int. Congress of Physiological Sciences. Budapest, 1980.

16. Lastkov D.O. Fiziologo-gigienicheskaia otsenka kombinirovannogo vozdeistviia na gornorabochikh lokal'noi vibratsii, shuma i nagrevaiushchego mikroklimata [Physiological and hygienic assessment of combined impact on miners of local vibration, noise and heating microclimate]. Meditsina truda i promyshlennaia ekologiia, 1998, no.4, pp. 4-8.

17. Katsai V.V. Vliianie shuma elektrooborudovaniia na elektrotekhnicheskie kharakteristiki tela cheloveka [Effect of electrical noise on electrical and technical characteristics of the human body]. Ph. D. thesis. Cheliabinsk, 2006, 108 p. 
18. Gerletka S. Vliianie ergonomicheskikh faktorov $\mathrm{v}$ ugol'nykh shakhtakh na elektrofiziologiiu cheloveka [Influence of ergonomic factors in coal mines on human electrophysiology]. Bezopasnost' truda $v$ promyshlennosti, 2003, no. 1, pp.59-63.

19. Zykina E.V., Eliseeva T.L., Triapitsyn A.B. Ustanovka dlia issledovaniia vliianiia shuma na elektricheskoe soprotivlenie tela cheloveka [Installation for study of the effect of noise on the electrical resistance of the human body]. Elektrobezopasnost', 2010, no.2-3, pp.67-70.

20. Sidorov A.I., Triapitsyn A.B., Zykina E.V., Eliseeva T.L. Ustanovka dlia issledovaniia vliianiia shuma na pervichnye kriterii elektrobezopasnosti [Installation for study the effect of noise on primary electrical safety criteria]. Patent 119503 Rossiiskaia Federatsiia no. 2012110085/12

21. Sidorov A.I., Triapitsyn A.B., Zykina E.V., Eliseeva T.L. Pervichnye kriterii elektrobezopasnosti pri sochetannom deistvii elektricheskogo toka i shuma [Primary criteria of electrical safety at joint effect of electric current and noise]. News of the Higher Institutions. Mining Journal, 2013, no.1, pp.22-25.

22. Pivniak G.G., Remizov I.P., Saratikiants S.A. et al. Transport $\mathrm{s}$ induktivnoi peredachei energii dlia ugol'nykh shakht [Transport with inductive energy transfer for coal mines]. Moscow, Nedra, 1990, 245 p.

23. Manoilov V.E. Osnovy elektrobezopasnosti [Basics of electrical safety]. Leningrad, Energoatomizdat, Leningradskoe otdelenie, 1991, $480 \mathrm{p}$.

24. Trofimov N.A. Otsenka uslovii truda v proizvodstvennykh pomeshcheniiakh po shumovomu faktoru [Estimation of working conditions in industrial premises by noise factor]. Nauchnye issledovaniia i innovatsii, 2009, vol.3, no.4, pp.95-97.

25. Balakina N.A., Shustitskii I.V. Optimizatsiia i avtomatizatsiia protsessa izmereniia i otsenki nepostoiannogo promyshlennogo shuma. Optimizatsiia proizvodstvennykh protsessov [Optimization and automation of the process of measuring and evaluating nonpermanent industrial noise. Optimization of production processes], available at: http://lib.sevsu.ru:8080/xmlui/handle/123456789/1 590 (accessed 15 August 2017).

26. Sedliarov O.I. Dozovaia otsenka shumovogo vozdeistviia na osnove modelirovaniia raboty tekhnologicheskogo oborudovaniia i kharaktera peremeshcheniia personala [Dose evaluation of noise impact on the basis of modeling the operation of process equipment and the nature of the movement of personnel], available at: http://www.gpss.ru/immod05/sd/sedlyarov/print.ht ml (accessed 15 August 2017).

27. Izmerov N.F., Suvorov G.A. Fizicheskie faktory proizvodstvennoi i prirodnoi sredy. Gigienicheskaia otsenka i kontrol' [Physical factors of the production and natural environment. Hygienic assessment and control]. Moscow, Meditsina, 2003, 556 p.

28. Suvorov G.A., Shkarinov L.N., Denisov E.I. Gigienicheskoe normirovanie proizvodstvennykh shumov i vibratsii [Hygienic regulation of production noises and vibrations]. Moscow, Meditsina, 1984, $240 \mathrm{p}$.

29. Zykina E.V., Sidorov A.I., Triapitsyn A.B. Metodika issledovaniia vliianiia postoiannogo shuma na velichinu porogovogo oshchutimogo toka [Method for studying the influence of constant noise on the threshold sensible current]. Dostizheniia nauki- 
agropromyshlennomu proizvodstvu. Materialy LI mezhdunarodnoi nauchno-tekhnicheskoi konferentsii. Cheliabinsk, 2012, part VI, pp.56-58.
30. Shchutskii V.I., Mavritsyn A.M., Sidorov A.I. et al. Elektrobezopasnost' na otkrytykh gornykh rabotakh [Electrical safety in open-pit mining]. Moscow, Nedra, 1983, 192 p.

\section{Библиографический список}

1. Скрипаль Б.А. Профессиональная заболеваемость, ее особенности на предприятиях горно-химического комплекса Кольского Заполярья // Экология человека. - 2008. № 10. - С. 26-30.

2. Окс Е.И., Куракин В.А., Абашкин А.О. Оценка условий труда и расчет допустимого (безопасного) стажа основных профессий угольных шахт Кузбасса // Медицина труда и экология человека. - 2015. - № 3. - С. 147-150.

3. Захаренков В.В., Кислицына В.В. Гигиеническая оценка условий труда и профессионального риска для здоровья работников угольной шахты // Успехи современного естествознания. - 2013. - № 11. C. $14-18$.

4. Чеботарёв А.Г. Современные условия труда на горнодобывающих предприятиях и пути их нормализации [Электронный ресурс] // Горная промышленность. - 2012. - № 2. URL: http://mining-media.ru/ru/article/prombez/24 99-sov-remennye-usloviya-truda-na-gornodobyvayushchikh-predpriyatiyakh-i-puti-ikh-normalizatsii (дата обращения: 15.08.2017).

5. Особенности формирования профессиональной заболеваемости у рабочих горнорудных предприятий / 3.С. Терегулова, Э.И. Таирова, Л.К. Каримова, Д.Р. Исхакова, Е.Р. Абдрахманова // Бюллетень ВСНЦ CO PAMH. - 2006. - № 3. - C. 109-110.

6. Влияние взрывоопасных газов, шума и вибрации угольных шахт на организм. Нистагм углекопов [Электронный ресурс] // Гигиена труда: сайт. - URL: http://meduniver.com/
Medical/gigiena truda/213.html) (дата обращения: 15.08.2017).

7. Колесниченко Е.А., Колесниченко И.Е. Причины и возможные методы предотвращения взрывов метана и пожаров в шахтах России [Электронный ресурс] // Горная промышленность. - 2004. - № 1. - URL: http://mining-media.ru/ru/article/prombez/1419prichiny-i-vozmozhnye-metody-predotvrashcheniya-vzryvov-metana-i-pozharov-v-shakhtakh-rossii (дата обращения: 17.08.2017).

8. Afanasieva R.F. Preventive measures of workers in cooling condition: hygienic and clinical bases of assessment and development // Problems with cold work. Int. Symposium. - Sweden, 1997. - P. 19-25.

9. McCarty D. Arthritis allied conditions: A Textbook of rheumatology. - 1988. - P. 224-241.

10. Петриченко С.И. Влияние условий труда и быта лиц геологических профессий на заболеваемость артериальной гипертонией и ишемической болезнью сердца: автореф. дис. ... канд. мед. наук. - М., 1997. - 24 с.

11. Rentzsch M., Presher W., Weinrich W. Combined effect of selected parameters of climate and noise on labour efficiency and stain // Combined effects of environmental factors / Ed. by O. Manninen. - Tampere, 1984. - P. 99-115.

12. Combined effects of vibration and noise palmar sweating in healthy subjects / H. Sakakibara, T. Kondo, Y. Koike [et al.] // European Journal of Applied Physiology and Occupational Physiology. - 1989. - Vol. 59, iss. 3. - P. 195-198. DOI: 10.1007/BF02386187. 
13. Бабаян М.А., Денисов Э.И. Сочетанное действие шума, тепла и оценка их биологической эквивалентности // Гигиена труда и профзаболевания. - 1991. - № 9. - С. 24-26.

14. Burstrom L. The influence of noise and temperature on the absorption of vibration energy in the hand // Archives of Complex Environmental Studies. - 1995. - 7(34). - P. 91-95.

15. Manninen O. Increased loss of hearing due to combined noise and low frequency vibration // 28th Int. Congress of Physiological Sciences, 13-19 July. - Budapest, 1980.

16. Ластков Д.О. Физиолого-гигиеническая оценка комбинированного воздействия на горнорабочих локальной вибрации, шума и нагревающего микроклимата // Медицина труда и промышленная экология. - 1998. № 4. - С. 4-8.

17. Кацай В.В. Влияние шума электрооборудования на электротехнические характеристики тела человека: дис. ... канд. техн. наук. - Челябинск, 2006. - 108 с.

18. Герлётка С. Влияние эргономических факторов в угольных шахтах на электрофизиологию человека // Безопасность труда в промышленности. - 2003. - № 1. C. 59-63.

19. Зыкина Е.В., Елисеева Т.Л., Тряпицын А.Б. Установка для исследования влияния шума на электрическое сопротивление тела человека // Электробезопасность. - 2010. - № 2-3. C. $67-70$.

20. Установка для исследования влияния шума на первичные критерии электробезопасности: пат. 119503 Российская Федерация № 2012110085/12 / Сидоров А.И., Тряпицын А.Б., Зыкина Е.В., Елисеева Т.Л.; заявл. 15.03.2012; опубл. 20.08.2012.
21. Первичные критерии электробезопасности при сочетанном действии электрического тока и шума / А.И. Сидоров, А.Б. Тряпицын, Е.В. Зыкина, Т.Л. Елисеева // Известия вузов. Горный журнал. - 2013. - № 1. - С. 22-25.

22. Транспорт с индуктивной передачей энергии для угольных шахт / Г.Г. Пивняк, И.П. Ремизов, С.А. Саратикянц [и др.]. - М.: Недра, 1990. - С. 245.

23. Манойлов В.Е. Основы электробезопасности. - 5-е изд., перераб. и доп. - Л.: Энергоатомиздат, Ленингр. отделение, 1991. - C. 480.

24. Трофимов Н.А. Оценка условий труда в производственных помещениях по шумовому фактору // Научные исследования и инновации. 2009. - Т. 3, № 4. - С. 95-97.

25. Балакина Н.А., Шустицкий И.В. Оптимизация и автоматизация процесса измерения и оценки непостоянного промышленного шума. Оптимизация производственных процессов [Электронный pecypc]. - URL: http://lib.sevsu.ru:8080/xmlui/ handle/123456789/1590 (дата обращения: 15.08.2017).

26. Седляров О.И. Дозовая оценка шумового воздействия на основе моделирования работы технологического оборудования и характера перемещения персонала [Электронный ресурс]. - URL: http://www.gpss.ru/immod05/sd/sedlyarov/print.ht $\mathrm{ml}$ (дата обращения: 15.08.2017).

27. Измеров Н.Ф., Суворов Г.А. Физические факторы производственной и природной среды. Гигиеническая оценка и контроль. - М.: Медицина, 2003. - С. 556.

28. Суворов Г.А., Шкаринов Л.Н., Денисов Э.И. Гигиеническое нормирование производст- 
венных шумов и вибраций. - М.: Медицина, 1984. - C. 240.

29. Зыкина Е.В., Сидоров А.И., Тряпицын А.Б. Методика исследования влияния постоянного шума на величину порогового ощутимого тока // Достижения науки - агропромышленному производству: материалы LI Междунар. науч.техн. конф. / ЧГАА. - Челябинск, 2012. Ч. VI. - C. 56-58.

30. Электробезопасность на открытых горных работах / В.И. Щуцкий, А.М. Маврицын, А.И. Сидоров [и др.]. - М.: Недра, 1983. - 192 с.

Please cite this article in English as:

Sidorov A.I., Zykina E.V., Kudryashov A.V., Kalinina A.S. Joint effect of physical factors of different nature on the human. Perm Journal of Petroleum and Mining Engineering, 2018, vol.17, no.1, pp.60-70. DOI: 10.15593/2224-9923/2018.1.6

Просьба ссылаться на эту статью в русскоязычных источниках следующим образом:

Сочетанное действие на человека физических факторов различной природы / А.И. Сидоров, Е.В. Зыкина, А.В. Кудряшов, А.С. Калинина // Вестник Пермского национального исследовательского политехнического университета. Геология. Нефтегазовое и горное дело. - 2018. - Т.17, №1. - C.60-70. DOI: 10.15593/2224-9923/2018.1.6 